\title{
Aminoguanidine exhibits an inhibitory effect on $\beta$-amyloid-induced damage in F98 glioma cells
}

\author{
TAO CHEN $^{1 *}$, XIAO-LI SUN ${ }^{2 *}$, XI-AI YANG ${ }^{1}$, JING-JING SHI $^{1}$, YI LIU $^{1}$ and JIA-MING GONG ${ }^{1}$ \\ ${ }^{1}$ Department of Neurology, Ankang City Central Hospital, Ankang, Shaanxi 725000; \\ ${ }^{2}$ Department of Neurology, Shangluo Central Hospital, Shangluo, Shaanxi 726000, P.R. China
}

Received March 18, 2016; Accepted February 27, 2017

DOI: $10.3892 / \mathrm{mmr} .2017 .7378$

\begin{abstract}
The present study investigated the role of aminoguanidine in the prevention of harmful effects in astroglioma F98 cells induced by $\beta$-amyloid treatment. MTT assay was used to analyze cell viability. Expression of inducible nitric oxide synthase (iNOS) was analyzed using western blot analysis. Treatment of the F98 cells with a $15 \mu \mathrm{M}$ concentration of $\beta$-amyloid for $12 \mathrm{~h}$ reduced cell viability to $18 \%$ compared with the control cells. However, pretreatment with a $30 \mu \mathrm{M}$ concentration of aminoguanidine for $12 \mathrm{~h}$ completely prevented the $\beta$-amyloid-induced reduction in cell viability. The production of ROS and the expression of iNOS were significantly $(\mathrm{P}<0.005)$ higher in the $\beta$-amyloid-treated F98 cells. Aminoguanidine pre-treatment inhibited the $\beta$-amyloid-induced increase in the expression of ROS, with increased mRNA and proteins levels of iNOS12 $\mathrm{h}$ following treatment at a $30 \mu \mathrm{M}$ concentration. The $\beta$-amyloid treatment also resulted in a marked increase in the expression of cyclooxygenase-2 (COX-2) in F98 cells. By contrast, pre-treatment with aminoguanidine for $12 \mathrm{~h}$ led to reduction in the mRNA and protein expression levels of COX-2. Pre-treatment of the F98 cells with aminoguanidine at a $30 \mu \mathrm{M}$ concentration for $12 \mathrm{~h}$ prior to incubation with $\beta$-amyloid significantly $(\mathrm{P}<0.002)$ reduced the expression of prostaglandin E2 (PGE2). Aminoguanidine pre-treatment also caused the inhibition of $\beta$-amyloid-induced translocation of nuclear factor (NF)- $\kappa \mathrm{B}$ p65 into the cytosol. Thus, aminoguanidine prevented $\beta$-amyloid-induced Alzheimer's disease through reductions in the expression levels of $\mathrm{NO}$, iNOS, PGE2 and COX-2, and the inactivation of $\mathrm{NF}-\kappa \mathrm{B}$. Therefore, aminoguanidine offers potential for use in the
\end{abstract}

Correspondence to: Dr Jia-Ming Gong, Department of Neurology, Ankang City Central Hospital, 85 Jinzhou South Road, Hanbin, Ankang, Shaanxi 725000, P.R. China

E-mail: gongjiaming074@hotmail.com

*Contributed equally

Key words: aminoguanidine, neurological, translocation, viability, Alzheimer's treatment of neurological disorders, including Alzheimer's disease.

\section{Introduction}

Alzheimer's disease (AD) is currently one of the most common neurodegenerative disorders, and a leading cause of memory loss and cognitive decline in patients (1). The mechanism of onset of neurodegenerative diseases and the various components responsible remain to be fully elucidated. It is well known that $\beta$-amyloid treatment causes neuron death and subsequently results in dementia $(1,2)$. Studies have revealed that $\beta$-amyloid is involved in regulating the activity of neurons and synapses, and its aggregation in nervous system tissues results in the development of neurological disorders (3). In the neuronal cells, $\beta$-amyloid induces degeneration through a cascade of cellular processes involving the generation of reactive oxygen species (ROS) and the induction of cell death (4). The use of ROS-quenching agents, including polyphenolic compounds and tocopherol, has been shown to inhibit the harmful effects induced by $\beta$-amyloid $(5,6)$. The consumption of food items rich in anti-oxidant compounds has also been shown to prevent the development of various neurological disorders (7). The anti-oxidative compounds exhibit their effect through inhibiting the activation of various factors associated with several pathways $(7,8)$.

Aminoguanidine is a low molecular weight compound, soluble in polar solvents (e.g. water) and exhibits a broad spectrum of activities (9). It is important in the inhibition of tissue damage in patients with diabetes mellitus (9). Treatment of animals with aminoguanidine efficiently prevents injury to the brain and stroke (10-12). Aminoguanidine treatment is promising in the improvement of spinal cord motor function following injury (13). It also prevents the initiation of reactions leading to the production of ROS and formation of inflammation following spinal cord injury (13). The present study aimed to investigate the role of aminoguanidine in the prevention of harmful effects in astroglioma F98 cells induced by $\beta$-amyloid treatment. It was observed that aminoguanidine prevented F98 cells from the $\beta$-amyloid-induced increase in the production of ROS, and the enhanced expression of prostaglandin E2 (PGE2) and cyclooxygenase $(\mathrm{COX})-2$, and inhibited the activation of nuclear factor $(\mathrm{NF})-\kappa \mathrm{B}$. 


\section{Materials and methods}

Cell line and culture. The F98 rat glioma cell line was purchased from the American Type Culture Collection (Rockville, $\mathrm{MD})$. The cells were grown as monolayer cultures in DMEM (Invitrogen; Thermo Fisher Scientific, Inc., Waltham, MA, USA) in $5 \% \mathrm{CO}_{2}$ at $37^{\circ} \mathrm{C}$. The medium was supplemented with $10 \%$ heat-inactivated fetal bovine serum (Invitrogen; Thermo Fisher Scientific, Inc.) with penicillin/streptomycin (Invitrogen; Thermo Fisher Scientific, Inc.).

Chemicals and reagents. Aminoguanidine and $\beta$-amyloid were obtained from Sigma-Aldrich; Merck Millipore (Darmstadt, Germany). Aminoguanidine was dissolved in distilled water to prepare $1 \mu \mathrm{M}$ stock solution and stored at $-10^{\circ} \mathrm{C}$.

Cell viability assay. The F98 cells were cultured at a density of $2 \times 10^{5}$ cells per $100 \mu \mathrm{l}$ of medium for $24 \mathrm{~h}$ in 96 -well cell culture microplates (Corning Life Sciences, Lowell, MA, USA). Following incubation, the medium was replaced with a medium containing various concentrations of aminoguanidine $(10,20,30$ and $40 \mu \mathrm{M})$ and incubated at $37^{\circ} \mathrm{C}$ for $12 \mathrm{~h}$. $\beta$-amyloid (15 $\mu \mathrm{M})$ was then added to each of the wells, and incubation was continued for $12 \mathrm{~h}$. The control cells, after $24 \mathrm{~h}$ culture, were incubated for $12 \mathrm{~h}$ in a medium containing $\beta$-amyloid (15 $\mu \mathrm{M})$. Subsequently, 3-(4,5-dimethylthiazol-2-yl)-2,5-diphenyltetrazolium bromide (MTT; $5 \mathrm{mg} / \mathrm{ml}$; Sigma-Aldrich; Merck Millipore) was added to the wells $(10 \mu \mathrm{l})$ and incubated for $4 \mathrm{~h}$ at $37^{\circ} \mathrm{C}$, followed by the addition of $100 \mu \mathrm{l}$ dimethyl sulfoxide to dissolve any formazan crystals formed. The enzyme-linked immunosorbent detector (Bio-Rad Laboratories, Inc., Hercules, CA, USA) was used to measure optical density at $570 \mathrm{~nm}$.

Reverse transcription-polymerase chain reaction (RT-PCR) analysis. Total RNA was isolated from the F98 glioma cells following treatment with aminoguanidine and/or $\beta$-amylase using TRIzol (Thermo Fisher Scientific, Inc.). The RNA samples $(1 \mu \mathrm{g})$ were then subjected to RT and PCR sequentially using a One Step RT-PCR kit (Qiagen Inc., Valencia, CA, USA). The primers used were as follows: COX-2, forward 5'-TTCAAATGAGATTGTGGGAAAAT-3' and reverse 5'-AGATCATCTCTGCCTGAGTATCTT-3'; iNOS, forward 5'-AGAGAGATCCGGTTCACA-3' and reverse 5'-CACAGA GCTGAGGGTACA-3'; COX-1, forward 5'-TGCCCAGCT CCTGGCCCGCCGCTT-3' and reverse 5'-GTGCATCAA CACAGGCGCCTCTTC-3'; GAPDH, forward 5'CGGAGT CAACGGATTTGGTCGTAT-3' and reverse 5'-AGCCTT CTCCATGGTGGTGAAGAC-3'. A Mastercycler (Eppendorf, Hamburg, Germany) was used to perform amplification of the cDNA strands using the following thermocycling sequence: Initial step at $50^{\circ} \mathrm{C}$ for $2 \mathrm{~min}$ and $95^{\circ} \mathrm{C}$ for $10 \mathrm{~min}$, followed by 30 cycles of $95^{\circ} \mathrm{C}$ for $15 \mathrm{sec}$ and $60^{\circ} \mathrm{C}$ for $1 \mathrm{~min}$. Following amplification, the products were run on $1.5 \%$ agarose gels, followed by ethidium bromide staining (Sigma-Aldrich; Merck Millipore).

Western blot analysis. Following treatment of the F98 cells with aminoguanidine and/or $\beta$-amyloid, F98 cells were subjected to on-ice lysis using lysis buffer $[100 \mathrm{mM} \mathrm{NaCl}$,
$20 \mathrm{mM}$ Tris- $\mathrm{HCl}$, (pH 7.8), 0.1\% NP-40], containing protease inhibitor cocktail (Roche Diagnostics GmbH, Mannheim, Germany) and dithiothreitol, $\mathrm{Na}_{3} \mathrm{VO}_{4}, \mathrm{NaF}$ and phenylmethane sulfonyl fluoride ( $1 \mathrm{mM}$ each). The homogenates were centrifuged at $4^{\circ} \mathrm{C}$ at $14,000 \mathrm{x}$ g for $15 \mathrm{~min}$, and the supernatant was collected and stored at $-80^{\circ} \mathrm{C}$ until further analysis. Total protein $(50 \mu \mathrm{g})$ was loaded per lane and separated on $10 \%$ SDS-PAGE gels by electrophoresis at $100 \mathrm{~V}$. The proteins were then electroblotted onto nitrocellulose membranes (Hybond ECL; GE Healthcare Life Sciences, Chalfont, UK). The non-specific sites on the membrane were blocked by incubation with $5 \%$ skim milk powder and $3 \%$ bovine serum albumin (BSA; Cayman Chemical Compnay, Ann Arbor, MI, USA) over a period of $2 \mathrm{~h}$ at room temperature. The blots were then probed by incubation with mouse monoclonal primary antibodies, diluted 1:500, overnight at $4^{\circ} \mathrm{C}$. The primary antibodies used were anti-iNOS (610600), PGE2 (610205), COX-2 (610203) and NF- $\mathrm{B}$ (558393) (all from BD Biosciences, San Jose, CA, USA). The membranes were washed with PBS three times, followed by incubation with a peroxidase-labeled anti-rabbit secondary antibody (1:10,000; catalog number- 611-103-122; R\&D Systems, Inc., Minneapolis, MN USA) for $1 \mathrm{~h}$ at room temperature. The ECL-western blot detection kit (NEN, MA) was used for the visualization of immunoreactivity.

Measurement of ROS generation. The production of ROS in F98 cells treated with aminoguanidine and/or $\beta$-amyloid was determined with dichlorofluorescein-diacetate (DCFH-DA) using flow cytometric analysis. The cells, following aminoguanidine and $\beta$-amyloid treatment or $\beta$-amyloid treatment alone (vehicle control), were collected, rinsed twice with ice-cold PBS, and suspended in PBS $\left(2 \times 10^{6}\right.$ cells $\left./ \mathrm{ml}\right)$. Subsequently, $500 \mu \mathrm{l}$ of this suspension was incubated for $45 \mathrm{~min}$ at $25^{\circ} \mathrm{C}$ in tubes containing DCFH-DA at a concentration of $5 \mu \mathrm{M}$. The generation of ROS in the F98 cells was determined via DCF fluorescence intensity using flow cytometry.

Analysis of the aggregation of PGE2 in cells. The F98 cells were incubated for $12 \mathrm{~h}$ in a medium containing $\beta$-amyloid and aminoguanidine (treated cells) or $\beta$-amyloid alone (vehicle control). Following incubation, the medium was removed and the cells were subjected to an enzyme immunoassay using a commercial kit (Invitrogen; Thermo Fisher Scientific, Inc.) according to the manufacturer's protocol. The ELISA reader system was then used for the determination of PGE2 accumulation in the cells.

Immunochemistry for analysis of $N F \kappa B$ translocation. Immunohistochemistry was performed using the Ventana EX system and a DAB universal kit (Ventana Medical Systems, Inc., Tucson, AZ, USA). Following treatment with aminoguanidine and/or $\beta$-amyloid, the F98 cells were fixed using paraformaldehyde at $4^{\circ} \mathrm{C}$ for $45 \mathrm{~min}$. The cells were then rinsed in PBS twice, followed by permeabilization in $0.2 \%$ Triton $\mathrm{X}-100$. Following washing with PBS, the cells were blocked in BSA for $45 \mathrm{~min}$ and finally incubated with the anti-NF- $\kappa \mathrm{B}$ antibody (dilution $1: 1,000$ ) for $3 \mathrm{~h}$ at $25^{\circ} \mathrm{C}$. Following rinsing with PBS, the F98 cells were incubated for $45 \mathrm{~min}$ at $25^{\circ} \mathrm{C}$ with FITC-conjugated anti-rabbit IgG (Sigma-Aldrich; Merck 
Millipore), and a fluorescence microscope (Carl Zeiss AG, Oberkochen, Germany) was used for cell analysis.

Statistical analysis. The data are presented as the mean \pm standard error of the mean of three independent experiments performed in triplicate. Statistical comparison of the mean values between data was performed using unpaired Student's t-tests. For statistical analysis of the data, Prism Software (GraphPad Software, Inc., La Jolla, CA, USA) was used. $\mathrm{P}<0.05$ was considered to indicate a statistically significant difference.

\section{Results}

Effect of aminoguanidine on the $\beta$-amyloid-induced decrease inF98 glioma cell viability. The analysis of the effect of $\beta$-amyloid revealed inhibition in the rate of viability of the F98 glioma cells $12 \mathrm{~h}$ following treatment. Incubation of the F98 cells with $\beta$-amyloid for $12 \mathrm{~h}$ at a concentration of $15 \mu \mathrm{M}$ reduced the viability to $18 \%$ (Fig. 1A). $\beta$-amyloid reduced the viability of F98 cells in a concentration- and time-dependent manner. The effect of aminoguanidine on the $\beta$-amyloid-induced inhibition in F98 cell viability was analyzed following treatment with concentrations of 10,20 , 30 and $40 \mu \mathrm{M}$. The results showed that pretreatment with $30 \mu \mathrm{M}$ aminoguanidine for $12 \mathrm{~h}$ completely prevented the $\beta$-amyloid-induced decrease in the viability of the F98 cells (Fig. 1B).

Aminoguanidine inhibits $\beta$-amyloid-induced increases in the expression of $N O$ and $i N O S$. The analysis of the expression levels of ROS and iNOS revealed significantly $(\mathrm{P}<0.005)$ higher expression following $\beta$-amyloid treatment in the F98 cells. Incubation of the F98 cells with a $15 \mu \mathrm{M}$ concentration of $\beta$-amyloid for $12 \mathrm{~h}$ led to a marked increase in expression levels of ROS and iNOS (Fig. 2A). In addition, F98 cells were pre-treated with aminoguanidine for $12 \mathrm{~h}$ prior to incubation with $\beta$-amyloid and the expression of ROS was analyzed. It was observed that aminoguanidine pre-treatment at a concentration of $30 \mu \mathrm{M}$ for $12 \mathrm{~h}$ inhibited the $\beta$-amyloid-induced increase in the expression of ROS completely (Fig. 2B). Aminoguanidine pre-treatment for $12 \mathrm{~h}$ at a $30 \mu \mathrm{M}$ concentration inhibited the iNOS protein expression in the F98 cells (Fig. 3).

Aminoguanidine inhibits $\beta$-amyloid-induced increase in the expression of PGE2 and COX-2 in F98 cells. Treatment of the F98 cells with $\beta$-amyloid for $12 \mathrm{~h}$ at a concentration of $15 \mu \mathrm{M}$ led to a marked increase in the expression of COX-2 (Fig. 4). However, pre-treatment of the F98 cells with various concentrations of aminoguanidine exhibited a concentration-dependent reduction in the expression of PGE2. Pre-treatment with a $30 \mu \mathrm{M}$ concentration of aminoguanidine for $12 \mathrm{~h}$ resulted in reductions in the mRNA levels corresponding to the expression of COX-2 to the same level as in the control cells (Fig. 5). The expression of PGE2 in the $\beta$-amyloid-treated cells was also markedly increased, compared with that in the control cells. However, pre-treatment of the F98 cells with aminoguanidine at a $30 \mu \mathrm{M}$ concentration for $12 \mathrm{~h}$ prior to incubation with $\beta$-amyloid significantly $(\mathrm{P}<0.002)$ reduced the expression of PGE2.
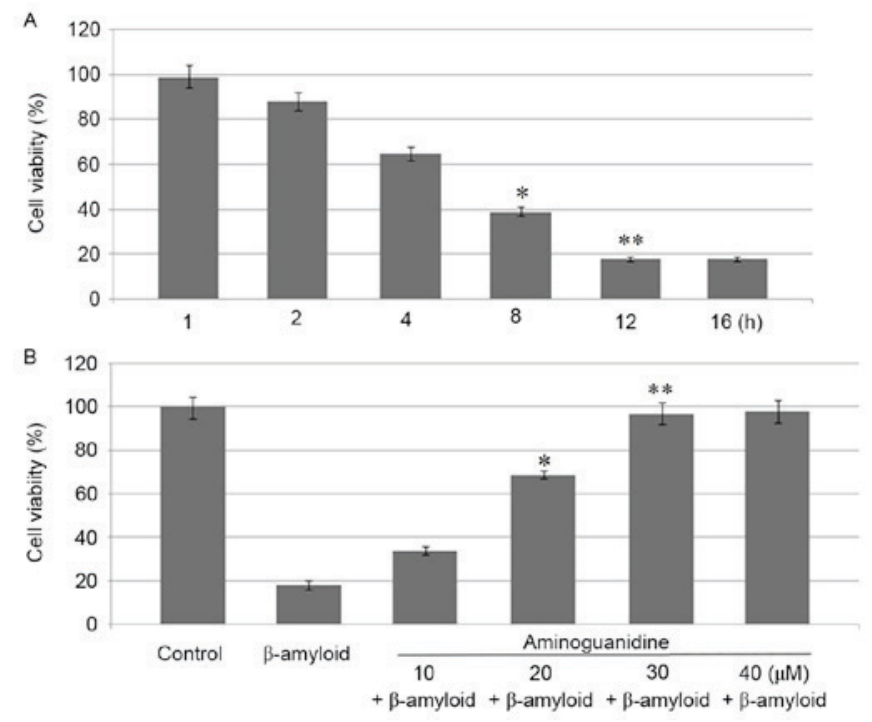

Figure 1. Aminoguanidine pre-treatment inhibits the $\beta$-amyloid-induced reduction in F98 glioma cell viability. (A) Cells at a density of $2 \times 10^{5}$ per $100 \mu \mathrm{l}$ were incubated with $15 \mu \mathrm{M} \beta$-amyloid. (B) Cells were pre-treated with $10,20,30$ and $40 \mu \mathrm{M}$ concentrations of aminoguanidine for $12 \mathrm{~h}$, followed by incubation with15 $\mu \mathrm{M} \beta$-amyloid. The cells were collected, rinsed in PBS and then analyzed for viability. Data are presented as the mean \pm standard error of the mean of three experiments performed independently. ${ }^{*} \mathrm{P}<0.005$ and ${ }^{* *} \mathrm{P}<0.002$ vs. control.

Repression of $\beta$-amyloid-induced nuclear translocation of $N F-\kappa B$ by aminoguanidine. Analysis of the localization of NF- $\kappa \mathrm{B}$ p65 in $\beta$-amyloid-treated F98 cells revealed its presence in the cell cytosol. By contrast, in the control cells, NF- $\kappa B$ p65 was confined to the cell nucleus alone (Fig. 6). In the F98 cells, pre-treatment with aminoguanidine resulted in the inhibition of NF- $\mathrm{KB}$ p65 translocation into the cytosol in a concentration-dependent manner. Following treatment with a $30 \mu \mathrm{M}$ concentration of aminoguanidine, the translocation of NF- $\mathrm{kB}$ p 65 from the nucleus to the cytosol was completely inhibited (Fig. 6).

\section{Discussion}

Alzheimer's disease, a frequently observed neurological disorder, is caused by the aggregation of $\beta$-amyloid in the central nervous system tissues (14). Alterations in the structure and function of neurons by the accumulation of $\beta$-amyloid results in the development of neuronal inflammation and the induction of apoptosis, which is characteristic of Alzheimer's disease (15). The expression of cytokines is higher in the nervous system tissues of patients with Alzheimer's disease (16). This suggests that the compounds, which inhibit the expression of cytokines can be important for the treatment of neurological disorders (16). COX-2 has been found to exhibit an important effect on the induction of inflammation in cells. It has been reported that, under normal circumstances, the expression of COX-2 in cells is negligible, whereas its expression is increased during various neurological disorders (17). The examination of nervous system tissues obtained from patients with neurological disorders has revealed markedly higher expression levels of COX-2 (17). It has been suggested that the expression 

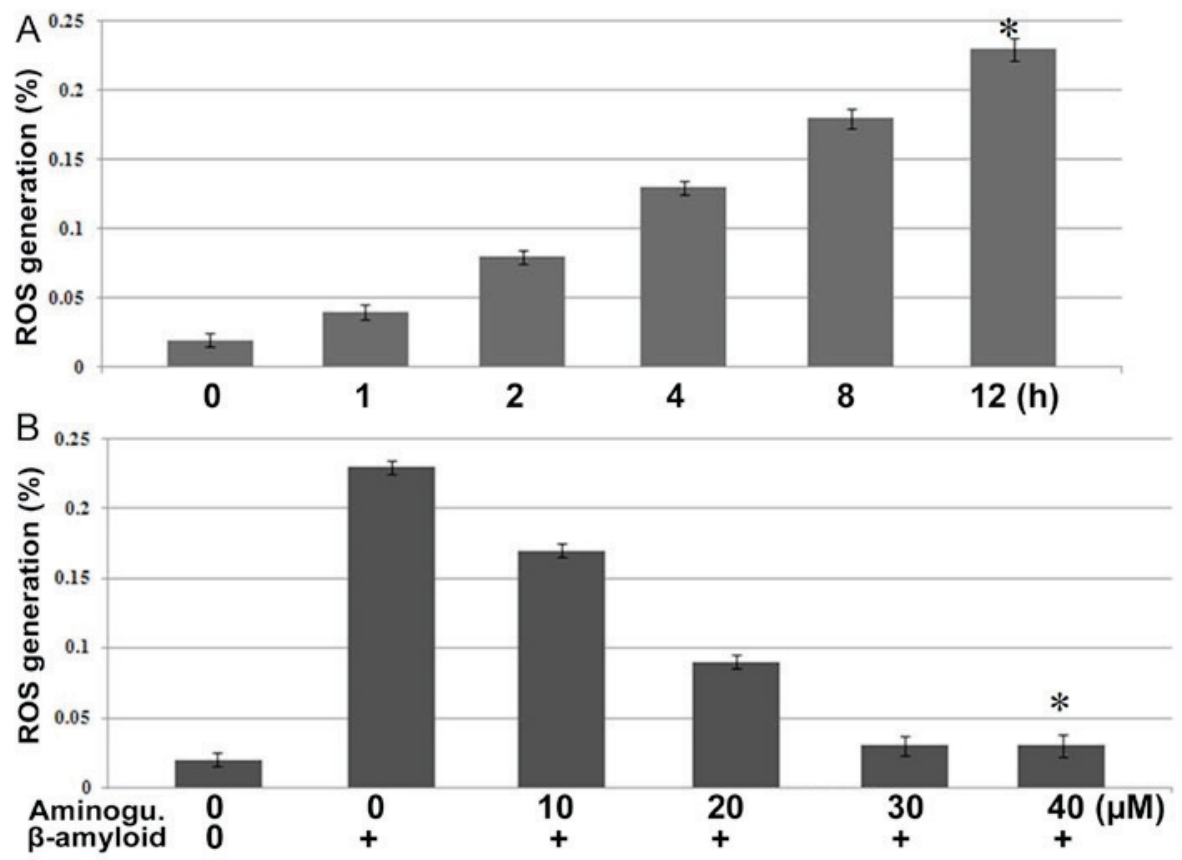

Figure 2. Aminoguanidine pre-treatment inhibits the $\beta$-amyloid-induced generation of NO in F98 cells. (A) Cells were seeded at a density of $2 \times 10^{6}$ cells $/ \mathrm{ml}$ and incubated with $15 \mu \mathrm{M} \beta$-amyloid. (B) Cells were pre-treated with $30 \mu \mathrm{M}$ aminoguanidine for $12 \mathrm{~h}$ and then incubated with $\beta$-amyloid. The generation of NO was analyzed by DCF fluorescence intensity using flow cytometry analysis of aminoguanidine-treated cells in comparison with control cells. NO, nitric oxide. ${ }^{*} \mathrm{P}<0.005$ vs. control.

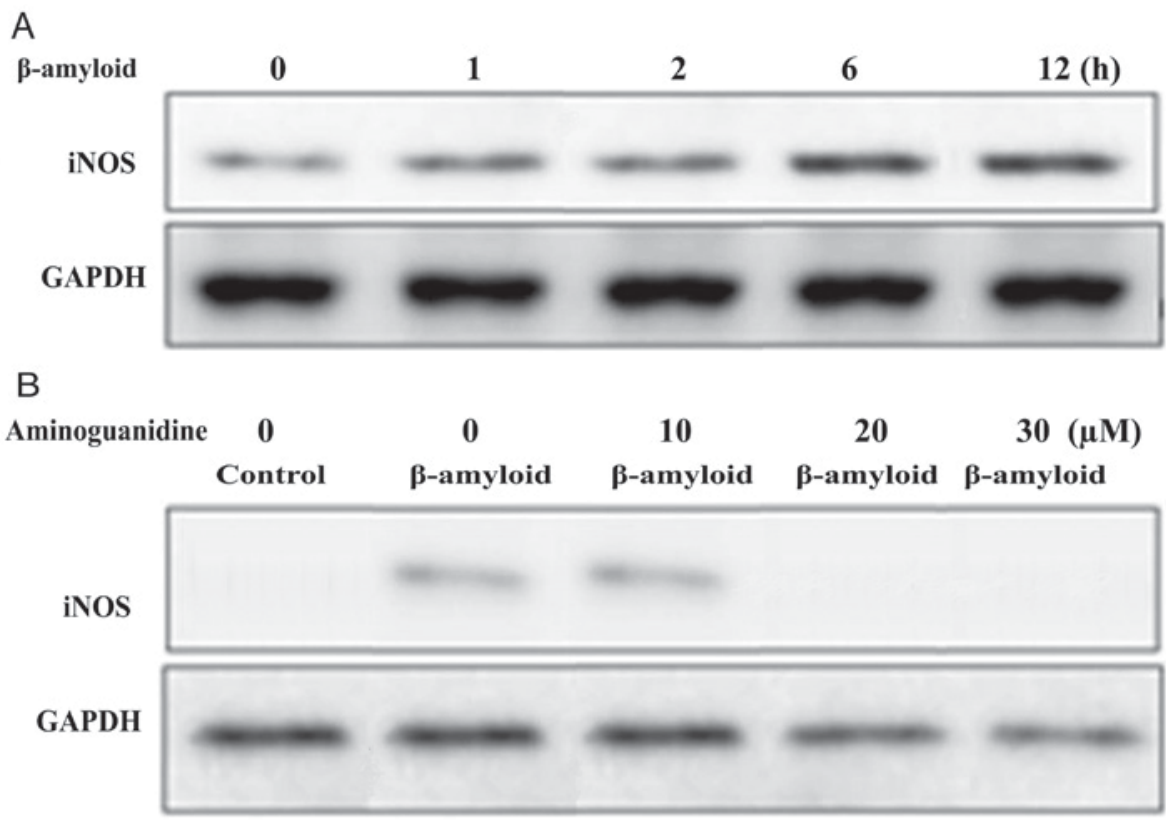

Figure 3. Aminoguanidine treatment of F98 cells inhibits the $\beta$-amyloid-induced increase in the expression of iNOS. (A) Cells incubated with $\beta$-amyloid were analyzed for the expression of iNOS. (B) Cells were pre-treated with $30 \mu \mathrm{M}$ of aminoguanidine for $12 \mathrm{~h}$ followed by incubation with $\beta$-amyloid. The cells were then analyzed for protein expression levels of iNOS. iNOS, inducible nitric oxide synthase.

of COX-2 leads to an increase in the production of ROS, which leads to neuron death (17). Studies have also demonstrated higher expression levels of PGE2 in the neuronal tissues of those suffering from neurological disorders (18). Thus, reducing the expression of PGE2 through the use of chemotherapeutic agents is considered to be an important strategy for the treatment of Alzheimer disease. The results from the present study demonstrated a significant decrease in the $\beta$-amyloid-induced expression of COX-2 and PGE2 when F98 cells were pre-treated with aminoguanidine.

The generation of ROS, including NO, in cells leads to alterations in several cellular processes and the development of disorders, including Alzheimer disease (19). The 


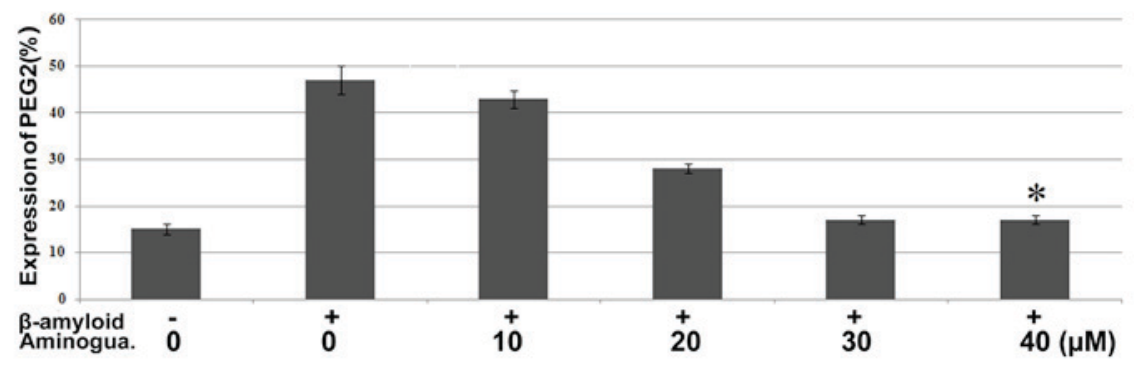

Figure 4. Aminoguanidine treatment inhibits the $\beta$-amyloid-induced increase in the expression of PGE2 in F98 cells. Cells were treated with $\beta$-amyloid or were pretreated with aminoguanidine followed by incubation with $\beta$-amyloid. The expression of PGE2 in aminoguanidine treated cells was analyzed in comparison with control cells. PGE2, prostaglandin E2. " $\mathrm{P}<0.002$ vs. control.

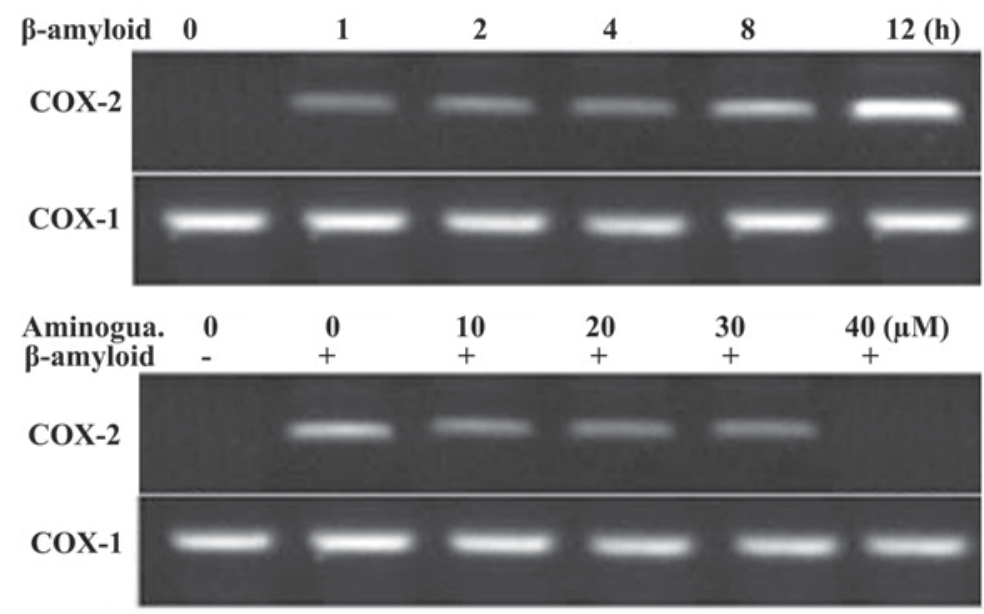

Figure 5. Aminoguanidine treatment inhibits the $\beta$-amyloid-induced increase in the expression of COX-2 in F98 cells. The cells were treated with $\beta$-amyloid alone or were pretreated with aminoguanidine followed by incubation with $\beta$-amyloid. The expression of COX-2 was then analyzed using reverse transcription-polymerase chain reaction analysis. COX, cyclooxygenase; aminogua, aminoguanidine.
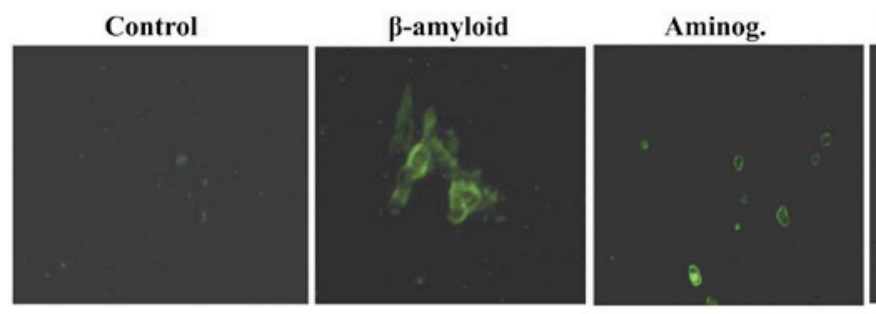

$\beta$-amyloid+Aminog.

Figure 6. Effect of aminoguanidine on the translocation of NF-кB induced by $\beta$-amyloid in F98 cells. The cells were treated with $\beta$-amyloid alone or were pretreated with aminoguanidine $(30 \mu \mathrm{M})$ followed by incubation with $\beta$-amyloid. The translocation of NF- $\mathrm{kB}$ was examined (magnification, $\mathrm{x} 200)$. NF- $\mathrm{kB}$, nuclear factor- $\kappa \mathrm{B}$; aminog, aminoguanidine.

production of NO takes place through the involvement of the enzyme, NOS (20). iNOS generates an increased quantity of NO, resulting in the development of inflammatory reactions. The results of the present study demonstrated that aminoguanidine pre-treatment of the F98 cells inhibited the $\beta$-amyloid-induced generation of NO and secretion of iNOS. The inhibition of iNOS secretion was evident at the mRNA and protein levels.

The activation of NF- $\kappa \mathrm{B}$ has been found in the neurological tissues of patients with Alzheimer disease during postmortem examination (21). The treatment of F98 cells with $\beta$-amyloid has also been found to induce the activation of NF-kB (22). In the present study, treatment of F98 cells with aminoguanidine resulted in the inactivation of NF- $\mathrm{KB}$ and the translocation of NF- $\mathrm{KB}$ into the nucleus.

In conclusion, aminoguanidine prevented $\beta$-amyloidinduced Alzheimer disease through reductions in the expression levels of NO, iNOS, PGE2 and COX-2, and the inactivation of NF- $\kappa \mathrm{B}$. Therefore, aminoguanidine offers potential for use in the treatment of neurological disorders, including Alzheimer's disease.

\section{Acknowledgements}

We would like to acknowledge the financial help offered by Ankang City Central Hospital (Shaanxi, China). 


\section{References}

1. Lewczuk P, Kamrowski-Kruck H, Peters O, Heuser I, Jessen F, Popp J, Bürger K, Hampel H, Frölich L, Wolf S, et al: Soluble amyloid precursor proteins in the cerebrospinal fluid as novel potential biomarkers of Alzheimer's disease: A multicenter study. Mol Psychiatry 15: 138-145, 2010.

2. Weiner MW: Dementia in 2012: Further insights into Alzheimer disease pathogenesis. Nat Rev Neurol 2: 65-66, 2013.

3. Tan L, Yu JT, Hu N and Tan L: Non-coding RNAs in Alzheimer's disease. Mol Neurobiol 47: 382-393, 2013.

4. Eckert A, Keil U, Marques CA, Bonert A, Frey C, Schüssel K and Müller WE: Mitochondrial dysfunction, apoptotic cell death, and Alzheimer's disease. Biochem Pharmacol 66: 1627-1634, 2003.

5. Canevari L, Abramov AY and Duchen MR: Toxicity of amyloid beta peptide: Tales of calcium, mitochondria, and oxidative stress. Neurochem Res 29: 637-650, 2004.

6. Grundman M, Grundman M and Delaney P: Antioxidant strategies for Alzheimer's disease. Proc Nutr Soc 61: 191-202, 2002.

7. Komatsu M and Hiramatsu M: The efficacy of an antioxidant cocktail on lipid peroxide level and superoxide dismutase activity in aged rat brain and DNA damage in iron-induced epileptogenic foci. Toxicology 148: 143-148, 2000.

8. Bastianetto S, Zheng WH and Quirion R: Neuroprotective abilities of resveratrol and other red wine constituents against nitric oxide-related toxicity in cultured hippocampal neurons. $\mathrm{Br}$ J Pharmacol 131: 711-720, 2000.

9. Abdel-Rahman E and Bolto WK: Pimagedine: A novel therapy for diabetic nephropathy. Expert Opin Investig Drugs 11: 565-574, 2002.

10. Di F, Yan-Ting G, Hui L, Tao T, Zai-Hua X, Xue-Ying S, Hong-Li X and Yun-Jie W: Role of aminoguanidine in brain protection in surgical brain injury in rat. Neurosci Let 448 : 204-207, 2008.

11. Sugimoto K and Iadecola C: Effects of aminoguanidine on cerebral ischemia in mice: Comparison between mice with and without inducible nitric oxide synthase gene. Neurosci Lett 331: 25-28, 2002.
12. Louin G, Marchand-Verrecchia C, Palmier B, Plotkine M and Jafarian-Tehrani M: Selective inhibition of inducible nitric oxide synthase reduces neurological deficit but not cerebral edema following traumatic brain injury. Neuropharmacology 50 : 182-190, 2006.

13. Pearse DD, Chatzipanteli K, Marcillo AE, Bunge MB and Dietrich WD: Comparison of iNOS inhibition by antisense and pharmacological inhibitors after spinal cord injury. J Neuropathol Exp Neurol 62: 1096-1107, 2003.

14. Hardy JA and Higgins GA: Alzheimer's disease: The amyloid cascade hypothesis. Science 256: 184-185, 1992.

15. Yankner BA, Dawes LR, Fisher S, Villa-Komaroff L, Oster-Granite ML and Neve RL: Neurotoxicity of a fragment of the amyloid precursor associated with Alzheimer's disease. Science 245: 417-420, 1989.

16. Raivich G, Jones LL, Werner A, Bluthmann H, Doetschmann T and Kreutzberg GW: Molecular signals for glial activation: Pro- and anti-inflammatory cytokines in the injured brain. Acta Neurochir Suppl 73: S21-S30, 1999.

17. Pasinetti GM: From epidemiology to therapeutic trials with anti-inflammatory drugs in Alzheimer's disease: The role of NSAIDs and cyclooxygenase in beta-amyloidosis and clinical dementia. J Alzheimers Dis 4: 435-445, 2002.

18. Montine TJ, Sidell KR, Crews BC, Markesbery WR, Marnett LJ, Roberts LJ and Morrow JD: Elevated CSF prostaglandin E2 levels in patients with probable AD. Neurology 53: 1495-1498, 1999.

19. Duncan AJ and Heales SJ: Nitric oxide and neurological disorders. Mol Aspects Med 26: 67-96, 2005.

20. MacMicking J, Xie QW and Nathan C: Nitric oxide and macrophage function. Annu Rev Immunol 15: 323-350, 1997.

21. Terai K, Matsuo A and McGeer PL: Enhancement of immunoreactivity for NF-kappa B in the hippocampal formation and cerebral cortex of Alzheimer's disease. Brain Res 735: 159-168, 1996.

22. Akama KT and van Eldik LJ: Beta-amyloid stimulation of inducible nitric-oxide synthase in astrocytes is interleukin-lbeta- and tumor necrosis factor-alpha (TNFalpha)-dependent, and involves a TNFalpha receptor-associated factor- and NFkappaB-inducing kinase-dependent signaling mechanism. J Biol Chem 275: 7918-7924, 2000 